\title{
MAZAGÃO - PORTA DO MAR: ESQUIZOANÁLISE APLICADA À HISTÓRIA - UMA CURA DA CURA*
}

\author{
Tarcísio Moreira Mendes \\ Sônia Maria Clareto
}

\section{Resumo:}

O mundo ocidental: uma longa História Universal, Branca e europeia. Captura, ou tende a capturar, todas as geografias do mundo Conhecido. O que produz uma aventura por caminhos de uma geografia da História? Ou, dito de outro modo, o que se produz numa cartografia dos movimentos históricos que constituem os universais da História da Humanidade? Como já denunciaram autores como Aimé Césaire e Frantz Fanon: foi preciso que a Civilização europeia se tornasse incivilizada para impor aos territórios ocupados a Civilização, uma violência histórica sem precedentes. Um exercício para curar da Cura: a esquizoanálise, como proposta por Félix Guattari e Gilles Deleuze, exercício de mapeamento de linhas de fuga do processo civilizatório que produziu enfermidades criminosas, como a escravização dos povos negros africanos. Uma aposta involutiva contra a Evolução imposta pelo ideal positivista que dominou as Ciências Modernas desde seu nascimento, estendendo seus estragos para campos como Cultura e Educação. $\mathrm{Na}$ intensificação do processo esquizoanalítico, será usado como dispositivo o filme "Mazagão - Porta do Mar” (2017), direção de Gavin Andrews e Cassandra Oliveira. No filme, moradores da comunidade de Mazagão Velho (AP), no Brasil, a historiadora Joseane Calazans e o artesão e produtor cultural Jozue Videira são convidados a visitar a antiga Mazagão, na costa do Marrocos. Este encontro produz uma ruptura entre a História tradicional praticada na cidade brasileira, fundamentada na cultura do cristianismo (que antagoniza com a cultura islâmica ou árabe). Jozue fica feliz em ver que a técnica usada por ele para fazer uma espécie de tambor é a mesma encontrada na cidade marroquina. Contrasta, com o longo silêncio diante da grande muralha, personagem das histórias tradicionais e orais de Mazagão Velho, ao se dar conta de que seus antepassados negros e islamitas não eram os do "mal" que expulsaram os portugueses do "bem". A ocupação de Mazagão marroquina pelos mazaganenses brasileiros é um Acontecimento no sentido em que leva ao limite o agenciamento do cristianismo, o limiar do Ideal entre a luta do "bem contra o mal". O acaso afirmado no encontro entre uma história cristã e um história islamita reivindica a afirmação de uma outra história, de uma outra vida: libera linhas de criação, linhas de fuga da hegemônica História Universal (afirmar o acaso é afirmar o universo sem finalidade, afirmar a vida como variação). Não se trata, pois, de uma simples troca de vetores, na qual os negros islamitas passariam a ser heróis e os cristãos brancos, os vilões. É mais complexo: trata-se de uma vida, pois, como atentam Guattari e Deleuze em aliança com Nietzsche e Pierre Klossowsk, n’O anti-Édipo, somos “todos os nomes da história", Homo historia. Assim, Jozue e Joseane, entregues ao acaso, produzem uma

\footnotetext{
* DOI - 10.29388/978-65-86678-51-2-0-f.213-230
} 
história outra, são produzidos por uma outra história, cada um a seu modo. Ele, com a música e o artesanato. Ela, com um livro. Uma cura da Cura se faz possível na invenção de uma história outra, uma história de si e do mundo, uma história contra as atrocidades do racismo.

Palavras-chaves: Esquizoanálise. Involução. Acontecimento. Agencimento.

Figuras 1, 2 e 3 - Captura de tela
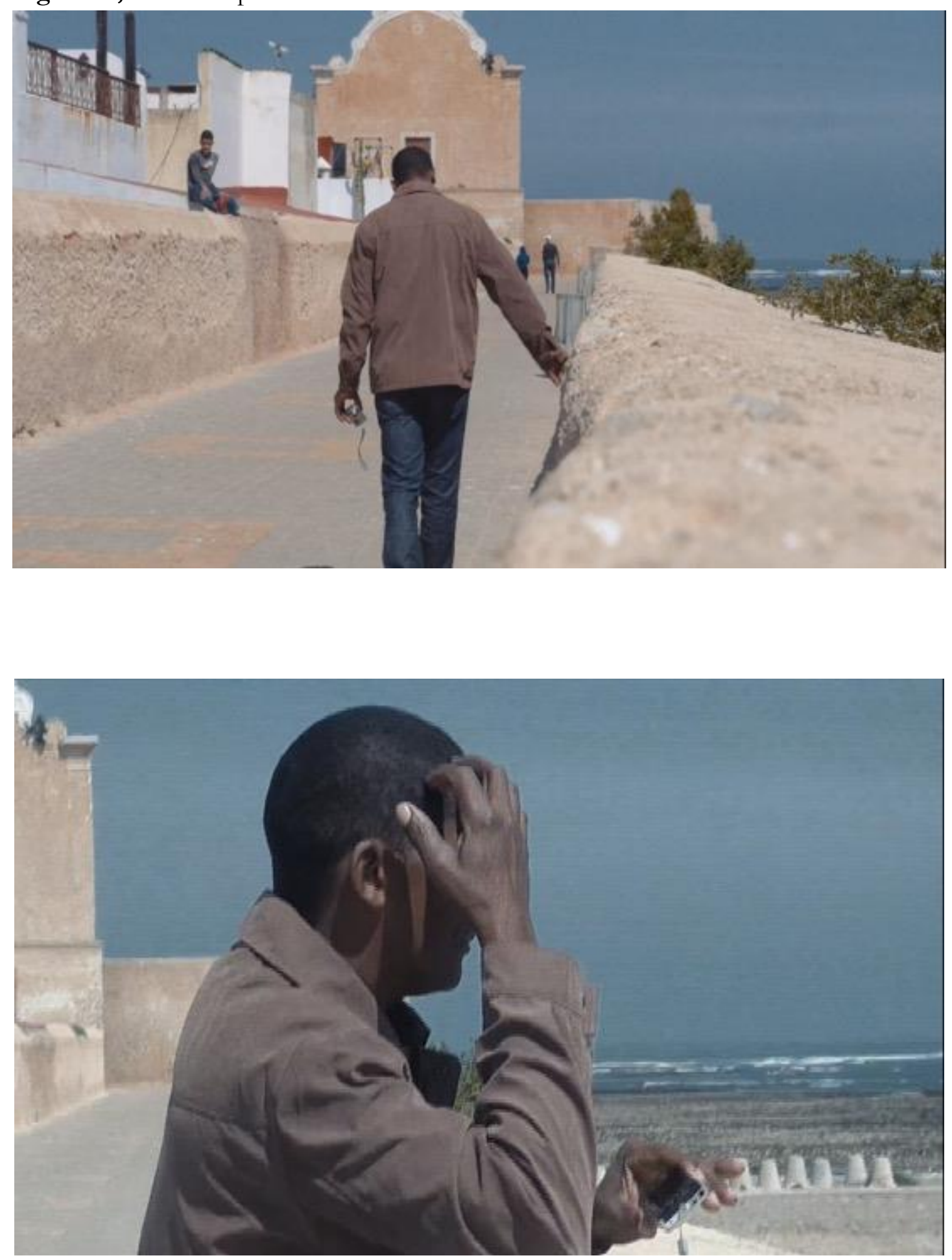


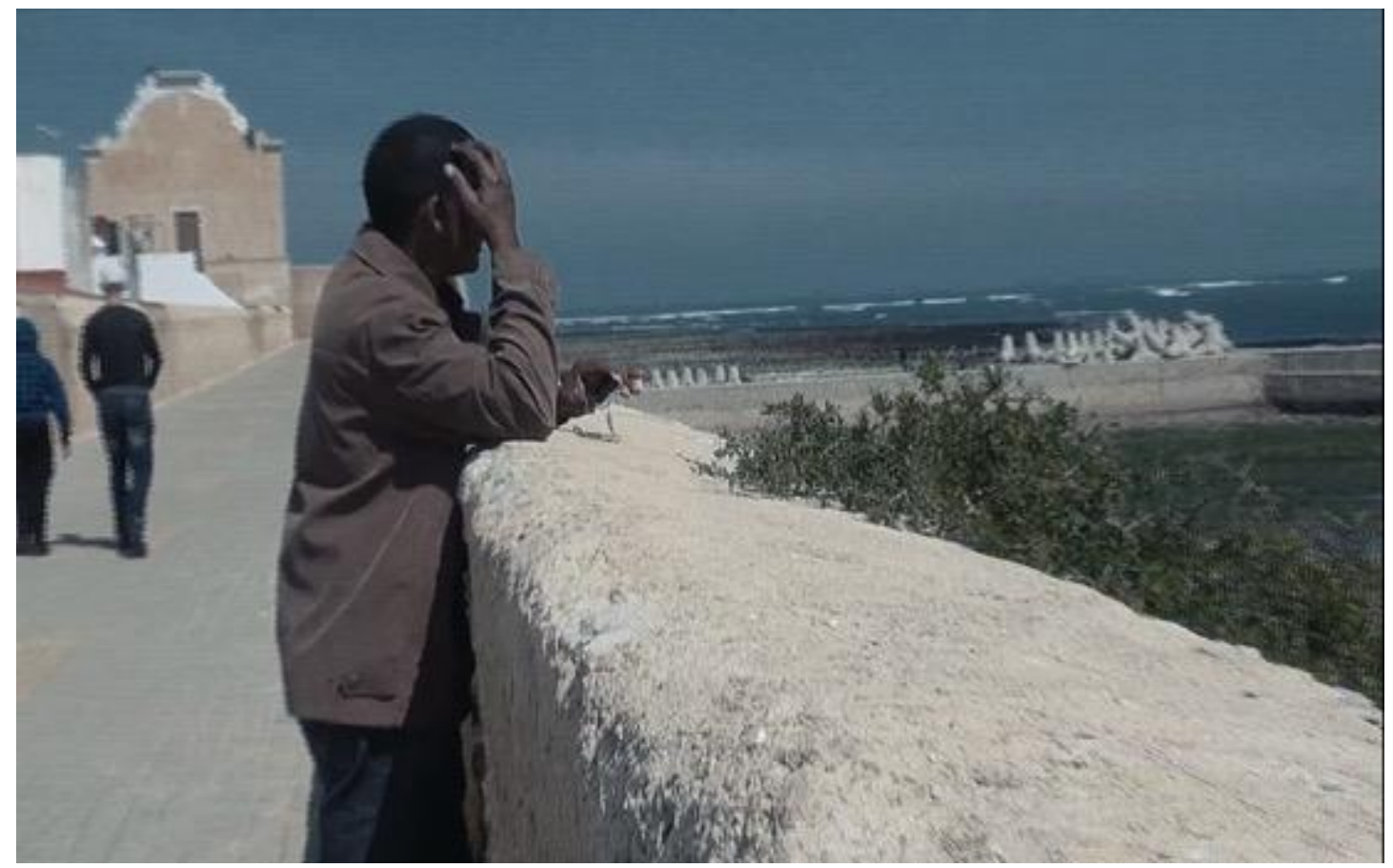

Fonte: MAZAGÃO, 2017

\section{A versão}

Em 10 de março de 1769, acuados por mulçumanos sanguinários, parte em retirada de Mazagão, na costa do Marrocos, território bravamente conquistado pela Coroa Portuguesa com as bençãos de Deus, toda a população portuguesa cristã que fazia daquela cidade sua casa no norte da África. Junto a homens brancos, homens e mulheres negres ${ }^{1}$ salvas pela escravização e conversão à Fé Católica, talvez um dia tivessem sido muçulmanas, carregam trouxas de roupa, malas e objetos de seus senhores e grandes estátuas de santos e santas cristãs-católicas. Católicos brancos e agora católicos negres, junto às tropas militares portuguesas, atravessam a fortaleza que com tanto orgulho protegeu a cidade da invasão estrangeira, de demônios de todos os tipos. Partem em direção a embarcações que têm como destino uma região segura no norte do Brasil, na Amazônia brasileira, que em homenagem à cidade abandonada e destruída, recebe o nome de Nova Mazagão. Para trás, deixam uma cidade, que antes era próspera e temente a Deus, entregue a povos muçulmanos que fazem uma guerra santa sem sentido e violenta, que querem impor sua fé a povos não-mulçumanos de toda a terra. A Porta do Mar fixa-se como última lembrança que resiste à violência inimiga dos temidos muçulmanos, a grande muralha que durante séculos protegeu da invasão de inimigos diversos. Uma população inteira cristã acuada e obrigada a fugir pelo mar em busca de uma nova terra e de uma nova vida, para enfim, conseguir, em paz, viver sua fé.

O mundo ocidental: uma longa História Universal, Branca e europeia, captura, ou tende a capturar, todas as geografias do mundo e produzir o Conhecido. Uma longa

\footnotetext{
${ }^{1}$ Usaremos, quando possível, termos que não intensifiquem a binaridade de gênero. Por isso, ao invés do uso do termo "negro" optamos por "negres", neste caso.
} 
História da Humanidade, logo, uma longa História por excelência, constituída por grandes acontecimentos que desencadeiam transformações numa relação de causa-efeito sistemática, numa linha contínua, feita de rupturas e novas criações provenientes de reapropriações das novidades. Novas criações que serviriam apenas para afirmar que o desconhecido é tudo aquilo que está pronto para ser Conhecido, desde já.

Para além da certeza dos movimentos que animariam estas transformações, o mais certo é que esta História teria, desde sempre, um sentido Único e Universalizante, tendo como pressuposto a Evolução, um sentido teleológico que tenderia ao aprimoramento. Qualquer coisa que viria a abalar uma regularidade estaria fadada a ser reinserida nesta linha temporal, apropriação e reapropriação. As variações seriam vistas como movimentos naturais do processo histórico, prontas para serem reagrupadas numa regularidade sempre pretendida. $\mathrm{O}$ acaso aqui é visto como um acidente, acidente previsível, algo inesperado dentro do esperado.

Que produz uma cartografia dos movimentos históricos que constituem os universais da História da Humanidade? O que produz uma aventura por caminhos de uma geografia da História?

Um diagnóstico nietzschiano para esta compreensão de História e de Humanidade, constituídas de grandes acontecimentos "ruidosos": seria preciso muito silêncio para que esses movimentos fossem tornados essenciais. "Universal e singular, imutável e particular, infinito e finito, o que é tudo isso? Nada além de sintomas" (DELEUZE, 1976, p. 73). Sintomas do quê? Sintomas de uma civilidade, de um adoecimento, da doença chamada Humanidade que assola a terra. Ou, dito de outro modo, como já denunciaram autores como Aimé Césaire (1978) e Frantz Fanon (1961/2005): foi preciso que a Civilização europeia se tornasse incivilizada para impor aos territórios ocupados a Civilização. Ou, foi preciso que a própria Europa fosse vítima da paranoia-reacionária ariana para que se desse conta das violências históricas sem precedentes produzidas em nome de uma Evolução, de uma Humanidade, do destino do Homem.

A Modernidade é a morte de Deus, ao mesmo tempo em que torna o Homem um deus: "Deus torna-se Homem, o Homem torna-se Deus. Mas quem é Homem? Sempre o ser reativo, o representante, o sujeito de uma vida fraca e depreciada. O que é Deus? Sempre o ser supremo como meio de depreciar a vida, 'objeto' da vontade de nada, predicado do 'niilismo'. Antes e depois da morte de Deus, o homem permanece 'quem é', assim como Deus permanece 'o que é': forças reativas e vontade de nada." (DELEUZE, 1976, p. 74). Deleuze, junto a Nietzsche, faz aqui a denúncia daquilo que levou a Modernidade aos maiores crimes contra Humanidade: o surgimento do ideal de Humanidade. Loucura, não? O Homem nasce já morto ao matar Deus e se colocar em seu lugar como um deus, o Homem feito Deus.

Um encontro - um acaso? - foi capaz de inventar a História como a compreendemos hegemonicamente hoje: "Em Hegel, trata-se de uma reconciliação: a dialética estava pronta a se reconciliar com a religião, com a Igreja, com o Estado, com todas as forças que alimentavam a sua" (DELEUZE, 1976, p. 74). Acaso aqui não é visto como um acidente, ou inesperado, mas como encontro, é o acaso do encontro que 
permitiu à máquina abstrata ${ }^{2}$ Hegel tal produção de agenciamento. A afirmação é uma afirmação da necessidade, afirmação como acaso. "Os dados lançados de uma só vez são afirmação do acaso, a combinação que formam ao cair é a afirmação da necessidade" (DELEUZE, 1976, p. 15). O novo agenciamento produzido pela máquina abstrata Hegel afirma uma combinação da necessidade. Deste modo, a afirmação do acaso foge a uma interpretação dialética ou acidental, ou insere a dialética na positividade do acaso. $\mathrm{O}$ acaso não é um inesperado. $\mathrm{O}$ acaso, aqui, é aquilo que revela a necessidade de sua afirmação, a combinação possível, efeito daquele encontro.

Temos aí uma denúncia do caráter teológico e cristão da filosofia, a impotência e negação da vida desta filosofia, a incapacidade da fuga da forma Homem, a reapropriação das transformações, sua reapropriação no tempo histórico. Uma transvaloração dos valores para superar a forma Homem é a proposta de Nietzsche anunciada por Deleuze. Transvalorar é sair da relação dialética que tem, como força reativa da Vida, o Homem. É abandonar o negativo como reapropriação da dialética, para além da forma Homem, na produção de uma forma que superaria a forma Homem: o super-homem, "uma nova maneira de sentir", "uma nova maneira de pensar", "uma nova maneira de avaliar" (DELEUZE, 1976, p. 76). O super-homem seria, então, este capaz de inventar e não apenas Conhecer o Mundo ou reconhecer a história universal, já que esta História é a priori niilista, o triunfo das forças reativas. Logo, a crítica é feita, um longo grito do homem superior diante da criação do super-homem. Não é apenas uma atenção ao que se tornou o Homem, como um acidente ou ao acaso. A crítica nietzschiana é a denúncia de uma enfermidade que adoece a terra desde seu surgimento. "A crítica de Nietzsche não combate um acidente, mas a própria essência do homem; é em sua essência que o homem é considerado doença de pele da terra" (DELEUZE, 1976, p. 77). Uma cura seria, pois, a superação da forma Homem. Ou ainda, mais urgente, seria preciso uma cura da Cura, uma cura ao que tem sido imposto a nós como Cura, ao longo de séculos, dialética e hegemonicamente às produções de vida, na pele da terra, ao corpo sem órgãos $(\mathrm{CsO})^{3}$. Uma fuga às estratificações que desejam conter os movimentos de vida da terra, uma desterritorialização para uma desestratificação.

Os estratos eram Camadas, Cintas. Consistiam em formar matérias, aprisionar intensidades ou fixar singularidades em sistemas de ressonância e redundância, constituir moléculas maiores ou menores no corpo da terra e incluir essas moléculas em conjuntos molares. Os estratos eram capturas; eram como 'buracos negros' ou oclusões que se esforçavam para reter tudo que passasse ao seu alcance. (DELEUZE, GUATTARI, 1995/2011b, p. 70).

\footnotetext{
2 “A máquina abstrata é sempre singular, designada por um nome próprio, de grupo ou de indivíduo, ao passo que o agenciamento de enunciação é sempre coletivo, no indivíduo como no grupo. Máquina abstrata-Lênin e agenciamento coletivo-bolchevique... O mesmo é válido para a literatura, para a música. Nenhum primado do indivíduo, mas indissolubilidade de um Abstrato singular e de um Concreto coletivo. A máquina abstrata não existe mais independentemente do agenciamento, assim como o agenciamento não funciona independentemente da máquina" (DELEUZE; GUATTARI, 1995/2011a, p. 48).

3 "Explicou que a Terra — a Desterritorializada, a Glaciária, a Molécula gigante — era um corpo sem órgãos. Esse corpo sem órgãos era atravessado por matérias instáveis não-formadas, fluxos em todos os sentidos, intensidades livres ou singularidades nômades, partículas loucas ou transitórias. Mas, no momento, essa ainda não era a questão. Pois, ao mesmo tempo, produzia-se na terra um fenômeno muito importante, inevitável, benéfico sob certos aspectos, lamentável sob muitos outros: a estratificação" (DELEUZE, GUATTARI, 1995/2011b, p. 70).
} 
Assim, não se trata de inventar um novo Homem ou uma nova subjetividade. A tarefa torna-se mais radical: trata-se de investigar as estratificações que se voltam contra o movimento do corpo da Terra. Uma cura da Cura não é, pois, intensificar os estratos de subjetivação e significância, aos quais o Homem está ligado, assim como está ligado à História. Uma cura da Cura se torna possível por meio da intensificação de processos de desterritorialização, de desestratificação, processos de dessubjetivação que inventam novas conexões com os movimentos do $\mathrm{CsO}$, a terra por vir. Para que não caiamos nos buracos negros da subjetividade, para fugir e fazer fugir a redundância e ressonância do significado e para liberar ainda mais linhas de fuga possíveis, é preciso mapear alguns estratos que nos aprisionam.

Deleuze e Guattari em sua conclusão da série Mil Platôs chamam atenção para os três grandes estratos, "fenômenos de espessamento no Corpo da terra, ao mesmo tempo moleculares e molares: acumulações, coagulações, sedimentações, dobramentos. São Cintas, Pinças ou Articulações. Tradicionalmente, distinguem-se, de modo sumário, três grandes estratos: físico-químico, orgânico, antropomórfico (ou 'aloplástico')" (DELEUZE; GUATTARI, 1997/2012b, p. 230). Aqui, consideremos ainda outros três estratos mais ligados ao antropomórfico ou "aloplástico", "[...] aqueles que nos amarram mais diretamente: o organismo, a significância e a subjetivação” (DELEZE; GUATTARI, 1996/2012, p. 25). Para fugir à dicotomia dos estratos, à dialética do positivo e do negativo, chamamos ainda atenção que um estrato pode servir a outro estrato como substrato, articulado por um agenciamento que sempre é territorial e desterritorializante, ligado ao movimento da terra, ao $\mathrm{CsO}$ ou ao plano de consistência.

As camadas eram os próprios estratos. Grupavam-se, no mínimo, aos pares, uma servindo de subestrato à outra. A superfície de estratificação era um agenciamento maquínico que não se confundia com os estratos. $\mathrm{O}$ agenciamento ficava entre duas camadas, entre dois estratos, tendo, portanto, uma face voltada para os estratos (nesse sentido era um interestrato), mas também uma face voltada para outro lugar, para o corpo sem órgãos ou plano de consistência (era um metaestrato). Na verdade, o próprio corpo sem órgãos formava o plano de consistência, que se tornava compacto ou mais espesso no nível dos estratos. (DELEUZE; GUATTARI, 1995/2011b, p. 70-71, grifos da obra original).

Um agenciamento que serve como um interestrato da dupla pinça entre um estrato e outro, também apresentaria uma dupla articulação. Na diferença à tradicional análise estratificada linguística de distinção entre forma e conteúdo, os dois pensadores apontam para as relações entre o agenciamento maquínico de expressão e o agenciamento de conteúdo ou de corpo, articulados por uma máquina abstrata.

E não haverá problema mais importante que este: considerando-se um agenciamento maquínico, qual é sua relação de efetuação com a máquina abstrata? De que modo ele efetua essa relação, com qual adequação? Classificar os agenciamentos. O que chamamos mecanosfera é o conjunto das máquinas abstratas e agenciamentos maquínicos, ao mesmo tempo, fora dos estratos, nos estratos e interestráticos" (DELEUZE; GUATTARI, 1995/2011a, p. 112). 
Não se trataria apenas de uma proposta oposta ou dialética à própria dialética. Cada agenciamento, de expressão e de conteúdo, teria sua diferença de natureza independente e, ao mesmo tempo, sempre em relação. Assim, é preciso mapear tais agenciamentos e máquinas abstratas para investigar suas produções. Esta articulação não seria dialética, já que ela não tende ao negativo e à reapropriação de uma linearidade e sim à produção de novas conexões, diagramas. O mapeamento dos estratos, assim como dos agenciamentos e das máquinas abstratas que os compõem, o plano de consistência, leva a territórios, a movimentos de desterritorializações relativas negativas, absolutas negativas e absolutas positivas.

Neste sentido, uma história islamita - que se tome como um novo processo, superação ou de antagonismo ao cristianismo - assim como uma história cristã - que tome o islamismo ou pagãos como inimigos a serem vencidos, superados - estão fadadas aos perigos da subjetivação, aos processos finitos e sucessivos, estratificados numa subjetividade, buracos negros, a velha cura pela dialética. Se nas histórias de Mazagão, tanto o islamismo como o cristianismo possuem movimentos de desterritorialização - "A função de desterritorialização: D [desterritorialização] é o movimento pelo qual 'se' abandona o território. É a operação da linha de fuga.” (DELEUZE; GUATTARI, 1997/2012a, p. 238) - percebemos também que tal desterritorialização encontra o absoluto, se conecta com a desterritorializada terra, mas mantém-se negativa, ao produzir um novo axioma ${ }^{4}$. Negativa porque o diagrama inventado pela máquina Cristo ou pela máquina Maomé, retém outras linhas de fuga, se reterritorializando na Bíblia ou no Corão, se reterritorializando no ressentimento, reatividade, produzem novas axiomáticas. Os dois livros, agora, nem são mais passíveis de interpretação, mas são tomados como Verdade a não ser questionada. Desse modo, um movimento que desterritorializa e desestratifica o cristianismo em direção à terra, se reestratifica, inclusive usando o próprio cristianismo como subestrato, para inaugurar uma nova estratificação ou subjetivação, o Islamismo. Ao mesmo tempo, o cristianismo revigora seu desejo de vingança, sua paranoia-reacionária, depois de usar como subestratos muitas territorialidades pagãs, sonhando um dia voltar à terra que fora forçado a abandonar.

\section{A OUTRA VERSÃO}

Em 10 de marco de 1769, povos islâmicos, depois de séculos, expulsam um grupo de cristãos portugueses que invadiram a região da costa atlântica do norte da África. Os cristãos partiram levando o que podiam de seus símbolos religiosos, acuados pelo poder e estratégia militar islâmica. Os cristãos portugueses partiram em direção a uma região da Amazônia brasileira, onde Marquês de Pombal, governador da Coroa Portuguesa em águas do Atlântico Sul, precisava garantir a ocupação de territórios na vasta colônia, temendo a

\footnotetext{
4 "Não confundiremos, especialmente, o diagramatismo com uma operação de tipo axiomático. Longe de traçar linhas de fuga criadoras e de conjugar traços de desterritorialização positiva, o axiomático barra todas as linhas, submete-as a um sistema pontual, e detém as escritas algébricas e geométricas que escapavam por todos os lados [...]. Escritas matemáticas se fazem axiomatizar, isto é, re-estratificar, re-semiotizar; fluxos materiais se fazem re-fisicalizar [...]. Programa de estrato contra diagrama do plano de consistência. O que não impede o diagrama de retomar seu caminho de fuga, e de espalhar novas máquinas abstratas singulares (é contra a axiomatização que se faz a criação matemática das funções improváveis, e contra a fisicalização que se faz a invenção material das partículas impossíveis de encontrar). (DELEUZE; GUATTARI, 1995/2011a, p. 107-108).
} 
invasão de espanhóis e de outros aventureiros. Os islamitas apagaram como puderam a história cristã que por séculos desejou submeter aquela área à Guerra Santa Católica, com a cumplicidade da Santa Sé. Para os derrotados, restou a lembrança da grande muralha que não foi capaz de proteger a cidade de Mazagão marroquina das estratégias militares arrojadas de povos islâmicos do norte da África. A retomada do território por seus antigos povos não impede que brancos cristãos levem consigo pessoas negras escravizadas e forçadas à conversão à fé católica. A Porta do Mar fixa-se na lembrança daquelas pessoas escravizadas como uma despedida triste da violenta retirada de sua terra para seguirem escravizadas em terras brasileiras, em nome de Deus. A imagem da grande muralha segue viva na memória negra como desejo de retorno à terra perdida e de reencontro com uma história negada e submetida à colonização pela cultura branca e, por isso, cristã.

Uma história particular diante daquilo que se queria Universal, mas, ainda, afirmação daquilo que se queria negar. Um movimento reativo diante da força ativa que deseja se afirmar.

A dialética nem mesmo aflora a interpretação, nunca ultrapassa o domínio dos sintomas. Confunde a interpretação com o desenvolvimento do sintoma não interpretado. Por isso, em matéria de desenvolvimento e de mudança, ela não concebe nada mais profundo do que uma permutação abstrata na qual o sujeito se torna predicado e o predicado, sujeito. (DELEUZE, 1976, p. 73)

A dialética convive com sua contradição, mas tende sempre à sua resolução, à sua superação histórica. A história neste sentido, nem seria superação das contradições, mas afirmação de um niilismo pela dialética. "O sentido da história e da dialética reunidas não é a realização da razão, da liberdade, nem do homem enquanto espécie, mas do niilismo, nada além do niilismo" (DELEUZE, 1976, p. 75). Niilismo como negação da vida, vontade de nada, negação da variação sem sentido prévio, negação da variação que é a própria Vida. Junto a Nietzsche, Deleuze vai diferenciar três tipos de niilismo: o niilismo negativo (momento da consciência judaico-cristã), quando o Deus judeu se faz Homem em Cristo condenado à morte pelos Homens, para morrer pelo Homem, passando de um Deus judeu a um Deus de todos os Homens, "um cosmopolita"; niilismo reativo (momento da consciência europeia), o Homem Europeu, aqui diríamos especificamente um Homem que se quer da raça superior, o Branco, substituição de Deus pelo homem reativo; e o niilismo passivo (momento da consciência budista), Cristo é aqui apresentado como aquele que exercita um modo budista, Cristo é aquele que ensina o homem reativo a morrer, para além do ressentimento ou da má consciência, aquele que não resiste ao mal e ao mesmo tempo ama o mal, não se defende e nem se encoleriza, pretende apenas provar que nasceu para aquilo, para o sofrer, sua força está na fraqueza.

A cultura islâmica é inserida na História Universal, por vezes, como uma desdobra do cristianismo. Nada muito diferente do que o cristianismo se propõe a fazer quando se agencia com o Império Romano: imposição de um Deus único, Verdadeiro, baseado na interpretação de um livro salvador. O islamismo opera, então, uma desterritorialização no estrato do cristianismo, mas se reterritorializa ao instalar-se sobre os estratos que pretendia abandonar. 
A D [desterritorialização] pode ser recoberta por uma reterritorialização que a compensa, com o que a linha de fuga permanece bloqueada; neste sentido, podemos dizer que a D [desterritorialização] é negativa. Qualquer coisa pode fazer as vezes de reterritorialização, isto é, 'valer pelo' território perdido; com efeito, a reterritorialização pode ser feita sobre um ser, sobre um objeto, sobre um livro, sobre um aparelho ou sistema... Por exemplo, o aparelho de Estado é erroneamente dito territorial: na verdade ele opera uma D [desterritorialização] que, no entanto, é imediatamente recoberta por reterritorializações sobre a propriedade, o trabalho e o dinheiro (é evidente que a propriedade da terra, pública ou privada, não é territorial, mas reterritorializante). Entre os regimes de signos, o regime significante atinge certamente um alto nível de D [desterritorialização]; mas, por operar ao mesmo tempo todo um sistema de reterritorializações sobre o significado, sobre o próprio significante, ele bloqueia a linha de fuga, e só deixa subsistir uma D [desterritorialização relativa] negativa" (DELEUZE; GUATTARI, 1997/2012a, p. 238)

O islamismo que desterritorializa a Bíblia se reterritorializa no Corão, na palavra mais Verdadeira das palavras de Deus na terra. Produz-se na afirmação reativa.

Se é possível perceber elementos de religiões ou cultos pagãos apropriados por cristãos e atacados pelo cristianismo, podemos perceber também aspectos dialéticos entre islamismo e cristianismo. Aspectos como o monoteísmo, a missão de conversão e intepretação dos livros sagrados (Bíblia e Corão), o Apocalipse e a doutrina "Jihad islâmico" (Guerra Santa Islâmica). "A subjetivação confere à linha de fuga um signo positivo, leva a desterritorialização ao absoluto, a intensidade ao mais alto grau, a redundância a uma forma refletida etc. Mas, sem recair no regime precedente, ela tem sua maneira própria de renegar a positividade que libera, ou de relativizar o absoluto que atinge" (DELEUZE; GUATTARI, 1995/2011a, p. 94). O cristianismo e o islamismo compartilham personalidades em suas crenças - como o Anjo Gabriel, Abraão e Jesus que, apesar de desempenharem papeis relacionáveis, produzem, fundamentalmente, diferenças. Ser islamita ou ser cristão: consciência e paixão que se alimentam da mesma força reativa. Podemos caracterizar o islamismo como uma reapropriação, como o triunfo de um homem superior, como observa Deleuze no estudo de Nietzsche:

O homem superior fica no elemento abstrato da atividade: mas não se eleva, nem mesmo em pensamento, até o elemento da afirmação. O homem superior pretende inverter os valores, converter a reação em ação [...]. Em lugar de um devir ativo, ela alimenta o devir inverso, devir-reativo. Em lugar de inverter valores, muda-se de valores, faz-se com que se permutem, mas conservando o ponto niilista do qual derivam; em lugar de adestrar as forças e torná-las ativas, organizam-se associações de forças reativas. (DELEUZE, 1976, p. 78)

O Islã nega o cristianismo ao negar Jesus como Cristo, como Salvação. Ao mesmo tempo, deslocando a figura de Jesus, não como salvador, mas como mais um profeta na esteira de Maomé, o último deles, o Islã reapropria-se, dialeticamente, da História do Homem. Institui um homem superior sem ultrapassar a forma homem, sem ir em direção ao super-homem, aquilo capaz de transvalorar os valores, fugir à dialética e, principalmente, fazer fugir a dialética 
Cristianismo e Islamismo: negação da vida na terra por afirmação de uma vida transcendental, metafísica. Afirmação do homem superior:

O que o homem superior apresenta como sendo a afirmação é, sem dúvida, o ser mais profundo do homem, mas é apenas a combinação extrema da negação com a reação, da vontade negativa com a força reativa, do niilismo com a má consciência e o ressentimento. Os produtos do niilismo é que se fazem carregar, as forças reativas é que carregam. (DELEUZE, 1997, p. 115-16)

Um perigo: assumir uma forma reativa; assumir a fraqueza niilista da vontade de nada de um ataque terrorista, autoritário, passional, cristão ou islâmico.

Cada consciência persegue sua própria morte, cada amor-paixão persegue seu próprio fim, atraídos por um buraco negro, e todos os buracos negros ressoando em conjunto. Com isso a subjetivação impõe à linha de fuga uma segmentaridade que não cessa de renegá-la, e impõe à desterritorialização absoluta um ponto de abolição que não cessa de barrá-la, de desviá-la. (DELEUZE; GUATTARI, 1995/2011a, p. 94)

Reatividade à força ativa, afirmação de uma vida como reação à força ativa de uma vida, e ao mesmo tempo, negação de vidas outras: ataque suicida.

\section{Uma transversão}

Em 2017, Jozue está sobre a muralha que ladeia a cidade de Al Jadida, no Marrocos, antiga cidade portuguesa de Mazagão ${ }^{5}$. Seu olhar é seguido de um longo silêncio que fita a imensidão do mar Atlântico. A sensação que se tem no encontro entre olhar, silêncio, mar, muralha, histórias é pura incerteza - é Porta do Mar, desterritorialização. Ou destruição de certezas históricas que, anos a fio, foram alimentadas por uma longa História da Humanidade. Jozue está diante da construção que povoa suas lembranças ancestrais, histórias narradas e recriadas na Velha Mazagão, no Estado do Amapá, Brasil, onde, na festa em homenagem ao santo católico, São Tiago, uma longa batalha é encenada, cristãos e islamitas guerreiam. O santo padroeiro católico da cidade brasileira, personificado por seu povo, é atingido pelo inimigo muçulmano e se perde em meio à multidão. $\mathrm{O}$ povo cristão perseguido é obrigado a encenar a evacuação da cidade atacada pelo povo islâmico. Partem bravamente, levando consigo o pouco que lhes resta, o ressentimento cristão e muita fé, que parece quase inabalada pela fúria de um povo que não é temente a Deus. De volta à terra de tantes e outres antepassades, cristãos e islamitas se encontram, cristãos e islamitas se confundem numa ancestralidade, cristãos e islamitas se desterritorializam, Mazagão e Al Jadida, senhores e escravizades. Os inimigos de outrora agora compartilham com Jozue os mistérios da artesania. Nas tramas do tambor marroquino, reconhecimento

\footnotetext{
${ }^{5}$ Mazagão - Porta do Mar (2017), direção de Gavin Andrews e Cassandra Oliveira. Uma produção de Espaço Cinema e Vídeo, com aporte financeira do Fundo Setorial de Audiovisual | Ancine através do BRDE, com apoio da EBC Empresa Brasil de Comunicação. Realização: Castanha Filmes. Produzido por Jurandir Costa. Trilha original de Aron Miranda. Direção de produção Ana Vidigal. Assistente de produção Thomé Azevedo. Produção de campo Carla Belas. Com Joseane Calazans, Jozue Videira e Rozicema Viana Barreto. A exibição do filme em plataforma digital para produção do artigo foi gentilmente cedida pela produção, a quem agradecemos muito!
} 
de traços brasileiros de uma tradição de esculpir a madeira, laçar fios e estirar o couro para produzir o som que embala tradições cristãs além-mar. Os aliados cristãos de antes são denunciados como conquistadores de terras que não lhes pertenciam, com desejo de destruição da fé que não professavam. Um longo silêncio. Muitas sensações. O olhar se lança novamente ao mar e a câmera na mão se torna obsoleta para o registro - Porta do Mar, desterritorialização atlântica. A distinção entre inimigos e aliados já não faz mais tanto sentido. A História já não faz qualquer sentido. O encontro entre mar, olhar, porta, islamismo e catolicismo, exige outros sentidos para uma história que se atualiza ali diante de tantas sensações inimagináveis.

"A pergunta é: como vencer o niilismo? Como mudar o próprio elemento dos valores, como substituir a negação pela afirmação?” (DELEUZE, 1976, p. 79). No filme "Mazagão - Porta do Mar" (2017), direção de Gavin Andrews e Cassandra Oliveira, moradores da comunidade de Mazagão Velho (AP), no Brasil - a historiadora Joseane Calazans e o diarista e artesão e produtor cultural ou do "movimento que protege e conserva a cultural", Jozue Videira - são convidades a visitar a antiga Mazagão, na costa do Marrocos. Este encontro produz uma ruptura entre a História tradicional praticada na cidade brasileira, fundamentada na cultura do cristianismo, na longa História da Humanidade (que antagoniza com a cultura islâmica, mulçumana ou árabe). Jozue fica feliz em ver que a técnica usada por ele para fazer uma espécie de tambor, por ele chamado de "caixa", é a mesma encontrada na cidade marroquina. A euforia anterior de Jozue contrasta com seu longo silêncio diante da grande muralha, personagem das histórias tradicionais e orais de Mazagão Velho, ao se dar conta de que antepassades negres e islâmicos não eram os do "mal" que expulsaram os portugueses do "bem".

Ao conjunto dos estratos, o $\mathrm{CsO}$ opõe a desarticulação (ou as $n$ articulações) como propriedade do plano de consistência, a experimentação como operação sobre este plano (nada de significante, não interprete nunca!), o nomadismo como movimento (inclusive no mesmo lugar, ande, não pare de andar, viagem imóvel, dessubjetivação.). (DELEUZE; GUATTARI, 1996/2012, p. 25-26)

O encontro, o acaso, afirma a necessidade. A experimentação faz fugir estratos, significações e subjetividades para islamitas e cristãos, nomadismo em direção à terra, conexão outra ao plano de consistência, desarticulando e ou produzindo $n$ articulações possíveis, tudo ao mesmo tempo, tudo num tempo outro. A ocupação de Mazagão marroquina pelos mazaganenses brasileires é um Acontecimento ${ }^{6}$ no sentido em que leva ao limite o agenciamento do cristianismo, o limiar do Ideal entre a luta do "bem contra o mal". O acaso afirmado no encontro entre uma história cristã e uma história islâmica reivindica a afirmação de uma outra história. Uma história ressentida e afirmada com força reativa: os islamitas feito vilões tornam-se vítimas e, por isso, heróis, uma reterritorialização torna-se possível. Ou afirmação ativa, desterritorialização absoluta positiva, que

\footnotetext{
6 “O possível não preexiste, é criado pelo acontecimento. É uma questão de vida. O acontecimento cria uma nova existência, [...] (novas relações com o corpo, o tempo, a sexualidade, o meio, a cultura, o trabalho, [a linguagem] [...]" (DELEUZE, GUATTARI, 2016, p. 246). Acontecimento: arrasta, com os possíveis que se abrem, a História e a Tradição para outros lugares, outros tempos, uma terra e um povo por vir. Acontecimento: podemos chamá-lo de "[...] 'cronogênese', se consideramos que se trata da lógica da gênese do próprio tempo, na medida em que são como que linhas de tempo que se abrem, estas múltiplas e imprevisíveis direções em que vai se produzindo a realidade” (ROLNIK, 1993, p. 03).
} 
diagramatiza em direção a uma nova terra feita de cura, uma história viva: libera linhas de criação, linhas de fuga da hegemônica História Universal - afirmar o acaso é afirmar o universo sem finalidade, afirmar a vida como variação. Não se trata, pois, de uma simples troca de vetores, na qual negres islâmicos passariam a ser heróis e cristãos brancos, os vilões.

\section{Estratos, território e desterritorialização}

Uma longa História da Humanidade pesa sobre os ombros do Homem, fazendoo por vezes rastejar como um animal sem similitude na Natureza. Libera uma bestialidade que nada tem a ver com as bestas, com animal que o Homem pensa rivalizar. Ou melhor, com o Animal que o Homem tenta aplacar, numa luta incessante contra a vida. O Homem como efeito de uma força reativa por excelência, uma força reativa que afirma, pela negação, a Vida: "E com o homem, é o mundo inteiro que se estraga e que se torna doente, é a vida toda que é depreciada, todo conhecido escorrega em direção ao seu próprio nada. Inversamente, a afirmação só se manifesta acima do homem, fora do homem, no sobre humano que ela produz, no desconhecido que traz consigo. Mas o sobre humano, o desconhecido também é o todo que rechaça o negativo" (DELEUZE, 1976, p. 81). Deleuze fala aqui da desterritorialização da forma Homem ou do Humano em direção ao que Nietzsche chama de "super-homem". Uma adjetivação que ora se confunde com aquele personagem que usa uma cueca vermelha sobre uma calça azul. No entanto, para além de uma lembrança da imagem do senso comum de um super-herói, com superpoderes, talvez o termo "super" não nos ajude a pensar ou a efetivamente produzir este "fora do homem" ou o "sobre humano" ou "além do homem" os quais Deleuze e Guattari destacam como forças de afirmação capazes de curar a terra da Cura.

Não se trata aqui de uma queda no indiferenciado. Joseane e Jozue, aos seus modos, nos encontros - puro acaso - afirmando necessidade, com os estratos nos quais estão instalades, mas seguindo linhas que desestratificam e desterritorializam territórios antes pensados imutáveis ou evolutivos. Criação, um novo agenciamento de enunciação (expressão) em conexão com o agenciamento de conteúdo (corpo), para produção de uma nova terra, sem se reterritorializar em ressentimentos, fugindo à afirmação reativa da vida. “Tanto a Josiane quanto eu, a gente tinha um objetivo, não só de ir a Mazagão visitar e conhecer, mas sim também, produzir alguma coisa, né, que a gente imaginasse" (MAZAGÃO, 2017, 45 min).

Despois de desterritorializades, depois de desterritorializar cristianismo e islamismo, uma História da Humanidade, uma História Universal, os dois se sentem obrigades a produzir um novo mundo que se agencia com uma nova terra por vir. Josiane se dispôs a escrever um livro. Jozue compõe uma canção para dar passagem àquela criação, para maquinar agenciamentos que atravessaram o limite entre o bem o mal produzido por uma História racista. Agora, atenção aos agenciamentos raciais para desterritorializar toda uma estratificação racista na produção de uma terra outra por vir, uma Mazagão outra por vir.

Um organismo, uma cinta que parecia inabalável, ou abalável em certo sentido dialético pressuposto, é desfeito para que outras coisas sejam feitas. Um estrato que parecia 
preso à carne da terra é desfeito. Mas que perigo!! "O que quer dizer desarticular, parar de ser um organismo? Como dizer a que ponto é isto simples, e que nós o fazemos todos os dias” (DELEUZE; GUATTARI, 1996/2012, p. 25-26). De uma história feita de muitos fios e linhas, um novo emaranhado, acontecimento. Um exercício, uma experimentação que lança efeitos para presente, passado e futuro. Que desterritorializa estrato temporal, que inaugura um novo tempo: acontecimento.

Caminhos de volta: de Mazagão Amapá a Mazagão africana Al Jadida. Mazagão, és o berço da cultura, teu povo clama sua história e devota sua fé. Teus registros estão nas fontes orais, nossas memórias são tuas referências, sua identidade é nossa cultura (MAZAGÃO, 2017, 46 min).

Tanto Josiane como Jozue não se entregam ao ressentimento ou à afirmação reativa ao identificar que seus antepassades negres, e provavelmente islâmicos, foram vítimas da escravização Branca. Nem ficam indiferentes ao saberem da versão de seus antepassades islâmicos. Um novo diagrama é produzido com a produção de Josiane e Jozue, onde é possível a afirmação ativa, a força da vida. Ao serem desterritorializades, entre cristianismo e islamismo, Josiane e Jozue entram em conexão intensiva com os movimentos da terra. Não há espaço para adoecimento, para ressentimento, para dialética, nem mesmo prognóstico de Cura. Suas criações oferecem uma prudência necessária à produção de vidas que ao mesmo tempo que dão cabo de um organismo que macula a terra, o racismo, lançam linhas de criação para uma cura da Cura.

Com que prudência necessária, a arte das doses, e o perigo, a overdose. Não se faz a coisa com pancadas de martelo, mas com uma lima muito fina. Inventam-se autodestruições que não se confundem com a pulsão de morte. Desfazer o organismo nunca foi matar-se, mas abrir o corpo a conexões que supõem todo um agenciamento, circuitos, conjunções, superposições e limiares, passagens e distribuições de intensidade, territórios e desterritorializações medidas à maneira de um agrimensor. (DELEUZE; GAUTTARI, 1996/2012, pp. 25-26)

Aproximações inimagináveis entre Mazagão brasileira e Mazagão marroquina, entre cristãos e islamitas. A surpresa em reconhecer os traços, o phylum maquínico que atravessa seu tambor brasileiro e o tambor marroquino; o longo silêncio e os pequenos movimentos que se encontram com a Porta do Mar - mistura de nostalgia e encantamento - imagem tão viva na sua memória antes mesmo de tê-la visto pela primeira vez, obriga Jozue a arriscar-se ainda mais no jogo da vida. Jozue é um jogador e lança os dados atento ao que vive, abandonando uma moralidade e escapando ao seu negativo. "O jogador abandona-se temporariamente à vida e temporariamente nela fixa o olhar: o artista se coloca temporariamente em sua obra e temporariamente acima dela: a criança joga, retirase do jogo e a ele volta" (DELEUZE, 1976, p. 14). Aqui não há espaço para subjetivação ou interpretação, é apenas produção. Jozue e Josiane feites máquinas abstratas, diagramatizando uma história outra. Jozue-artista-criança afirma o ser do devir, a transmutação ou a transvaloração de uma história.

Vejamos que diz Jozue a respeito de sua criação e da criação de Josiane e como isto se relaciona com a produção coletiva de sua comunidade, como isto inaugura um novo 
agenciamento coletivo de enunciação que nada tem a ver com o ressentimento cristão, nem tampouco islâmico. E como se abre para a produção de um novo agenciamento de conteúdo, de corpo.

Já que Joseane tem habilidade de escrever, e a gente também tem aquela habilidade de fazer a música porque não fazer uma música? A música ela vai mais fundo, ela atinge mais rápido o ser humano, ela vai mais fundo na consciência do ser humano. Por que não fazer uma música falando daquele povo e da nossa viagem? Acho que qualquer mazaganense ele sempre teve este sonho, de ir até essa outra Mazagão de onde vieram nossos antepassados, porque a gente ouve as pessoas falarem muito, mas a gente então sabia da nossa realidade, e não sabia da realidade do povo marroquino, então o fundamental disso era que a gente também pudesse ouvi-los e vê essa realidade deles, algumas questões que talvez eram mal ditas ou mal faladas... então a gente acabava julgando de uma forma diferente, quando você vai e vive essa realidade você vai ver que as coisas eram muito mais diferentes que a gente imagina, eu digo que foi o ponta pé fundamental dessa viagem, foi este contato, indo até a nova Mazagão lá como era, Al Jadida hoje e poder ouvir aquele povo e sentir que ele é um povo sim é humilde, hospitaleiro e educado por cima de tudo e religioso... então eles só apenas defenderam a religião deles, defenderam o gosto pessoal deles, que isso é um direito de cada um. Então, hoje eu vejo que a festa de São Tiago ela precisa sim, não que seja mudada, mas que passe por algumas formas de encenação, para que essas mensagens venham em seguida dessas encenações, para também mostrar pra eles que a gente mudou nosso pensamento em relação a eles, com todo respeito à religião, à cultura e ao modo de vida deles. Isso trouxe uma nova dimensão pra nossa história" (MAZAGÃO, 2017, $48 \mathrm{~min}$ ).

Está tudo aí, uma prudência necessária, com uma lima muito fina e não a pancadas de martelo: "[...] hoje eu vejo que a festa de São Tiago ela precisa sim, não que seja mudada, mas que passe por algumas formas de encenação" (MAZAGÃO, 2017, 48 min); distribuição de intensidades, de territórios e de desterritorializações, abrindo o corpo e sendo aberto a novas conexões e por novas conexões. Não se trata de um mero suicido ou assassínio de um organismo, mas conexões vivas outras: “[...] então quando você vai e vive essa realidade você vai ver que as coisas eram muito mais diferentes que a gente imagina, eu digo que foi o ponta pé fundamental dessa viagem, foi este contato, indo até a nova Mazagão lá como era, Al Jadida hoje e poder ouvir aquele povo [...] eles só apenas defenderam a religião deles, defenderam o gosto pessoal deles" (MAZAGÃO, 2017, 48 min). Por fim, apresentase o agrimensor, que não mede apenas sua distância do outro, mas produz uma nova distribuição da terra: "Isso trouxe uma nova dimensão pra nossa história". A proposta de uma nova dimensão histórica feita por Jozue não parte de uma evolução, de um aprimoramento, mas é feita de um encontro, acaso, que exige uma criação diante daquela nova conexão, afirmação da necessidade. "É uma involução. Uma involução criativa e sempre contemporânea” (DELEUZE, GUATTARI, 1996/2012, p. 31). Não há passado a ser restituído no presente, nem futuro a ser projetado. É um presente que se inventa com as novas conexões experimentadas.

O modo com o qual Jozue é posto a criar, primeiro desterritorializa o território do qual parte e impede uma reterritorialização no já conhecido. Não é um mero processo de 
sujeição, dito de outro modo, não é movimento de desterritorialização relativa negativa, que levaria à criação de um novo símbolo. Sua produção é desterritorialização absoluta positiva, que lança linhas em direção a uma terra por vir. Um possível de cura da Cura, pois não inventa um novo território na reterritorialidade ou desterritorialização adoecida e suicida, num desejo afirmativo reativo. É desterritorialização absoluta positiva por sempre ter um pequeno pedaço de terra a se aventurar. Por resguardar um pouco de organismo para que não caia no fosso do indiferenciado que levaria tudo à abolição absoluta.

Enfim de modo algum a terra é o contrário da D [desterritorialização]: isto já é o que se vê no mistério do 'natal', onde a terra como lar ardente, excêntrico ou intenso, está fora do território e só existe no movimento de D. Porém, mais ainda, a terra, o glaciário, é a Desterritorializada por excelência: nesse sentido pertence ao Cosmo, e se apresenta como o material graças ao qual o homem capta as forças cósmicas. Cabe dizer que, enquanto desterritorializada, a própria terra é o estrito correlato da D. A ponto de se poder nomear a D criadora da terra - uma nova terra, um universo, e já não só uma reterritorialização. (DELEUZE; GUATTARI, 1997/2012a, p. 239)

Isto quer dizer que a produção de Jozue não produz uma reterritorialização, mas opera uma desterritorialização absoluta positiva em direção a uma nova terra. Não se trata, pois, de substituir os vencidos por vencedores, cristãs por islamitas. Trata-se de conviver, de fazer conexão a forças afirmativas, estas forças de vida, a vida da terra. Não se trata da História dos vencidos tomada em substituição à História dos vencedores, trata-se de produzir ou de afirmar as forças históricas, as forças que inclusive alimentam a História, mas, aqui, escapam à História. É afirmar a disputa, a vida que pulsa que exige que inventemos uma nova terra para fugir e fazer fugir o ressentimento e a afirmação reativa.

Conectar, conjugar, continuar: todo um 'diagrama' contra os programas ainda significantes e subjetivos. Estamos numa formação social; ver primeiramente como ele é estratificado para nós, em nós, no lugar onde estamos; ir dos estratos ao agenciamento mais profundo em que estamos envolvidos; fazer com que o agenciamento oscile delicadamente, fazê-lo passar do lado do plano de consistência" (DELEUZE; GUATTARI, 1996/2012, p. 27)

A viagem de mazaganenses a Mazagão (que agora também se tornou velha por se tornar Al Jadida) desterritorializa mazaganenses brasileires e marroquines. As máquinas abstratas Josiane e Jozue operam uma delicada oscilação no agenciamento cristão que não deixa mais possível ver islamitas como meros violões que não reconhecem a verdadeira fé cristã. O novo agenciamento inaugurado em Josiane e Jozue diagramatiza uma nova terra, um plano de consistência, que esconjura programas significantes e subjetivos para cristãs e islamitas. "Plano de consistência é o conjunto de CsO" (DELEUZE; GUATTARI, 1996/2012, p. 22). O encontro entre mazaganenses de Brasil e Marrocos faz passar intensidades por um $\mathrm{CsO}$ cristão em conexão com um $\mathrm{CsO}$ islâmico em conexão com um $\mathrm{CsO}$ da terra em direção a um plano de consistência, na invenção de uma nova terra. 


\section{Diagramatização: a cura da Cura}

Um exercício para curar da Cura: a esquizoanálise, como proposta por Félix Guattari e Gilles Deleuze, exercício de mapeamento de linhas de fuga do processo civilizatório que produziu enfermidades criminosas, como a escravização dos povos negros islâmicos. Uma conexão involutiva ${ }^{7}$ contra a Evolução imposta pelo ideal positivista que dominou as Ciências Modernas desde seu nascimento, estendendo seus estragos para campos como Cultura e Educação. É mais complexo: trata-se de uma vida, pois, como atentam Guattari e Deleuze em aliança com Nietzsche e Pierre Klossowsk, n'O anti-Édipo (2010), somos "todos os nomes da história", Homo historia. Assim, Jozue e Joseane, entregues ao acaso, afirmando necessidade, produzem uma história outra, são produzides por uma outra história, cada um a seu modo, mas em conexão. Ele, com a música e o artesanato. Ela, com um livro. Juntes diagramatizam uma história que anuncia uma nova terra ainda por vir. Uma cura da Cura se faz possível na invenção de uma história outra, uma história de si e do mundo, uma história contra as atrocidades do racismo.

Curar a cura da Cura é lance de dados, acaso, encontro que revela, como acontecimento, a necessidade, as questões atuais que o próprio encontro impõe:

[...] instalar-se sobre um estrato, experimentar com ele, buscar aí um lugar favorável, eventuais movimentos de desterritorialização, linhas de fuga possíveis, assegurar aqui e ali conjunções de fluxos, experimentar segmento por segmento dos contínuos de intensidade, ter sempre um pequeno pedaço de uma nova terra. (DELEUZE; GUATTARI, 1996/2012, p. 27)

Não se trata, pois, de dar um novo sentido histórico, de superação de um modelo e imposição de outro. $\mathrm{Na}$ diferença a isso, trata-se de denunciar que o próprio sentido histórico é adoecido, efeito do e feito pelo niilismo, instinto de vingança, ressentimento, má consciência e passividade. Este texto é também fruto do acaso, fruto do encontro entre Mazagão marroquina e Mazagão brasileira e Jozue e Josiane e Gavin Andrews e Cassandra Oliveira e Lei estatal de incentivo audiovisual e Sônia e Tarcísio e Nietzsche e Deleuze e Guattari e Antonio Miguel e Carlos Viana e Júlio Corrêa, um lance de dados na superação do último Homem, do homem superior, para dar passagem, quem sabe, a um além do homem que não tenha mais o Homem como medida, abandono da dialética, cura da Cura.

De Mazagão em Al Jadida,

Pra Mazagão, no Amapá,

Revivemos nossa história, agora vamos contar. (bis)

Ao chegar em Al Jadida

\footnotetext{
7 'Preferimos então chamar de 'involução' essa forma de evolução que se faz entre heterogêneos, sobretudo com a condição de que não se confunda a involução com uma regressão. O devir é involutivo, a involução é criadora. Regredir é ir em direção ao menos diferenciado. Mas involuir é formar um bloco que corre seguindo sua própria linha, 'entre' os termos postos em jogo, e sob as relações assinaláveis” (DELEUZE; GUATTARI, 1997/2012b, p.19).
} 
Bateu forte o coração

Hoje falo pro meu povo

Fui na outra Mazagão (bis)

De Mazagão em Al Jadida,

Pra Mazagão, no Amapá,

Revivemos nossa história, agora vamos contar. (bis)

Hoje falo com firmeza

Porque eu estive lá

Conheci um povo guerreiro

Que lutou por seu lugar (bis)

De Mazagão em Al Jadida,

Pra Mazagão, no Amapá,

Revivemos nossa história,

agora vamos contar. (bis) ${ }^{8}$

Figura 4 - Captura de tela

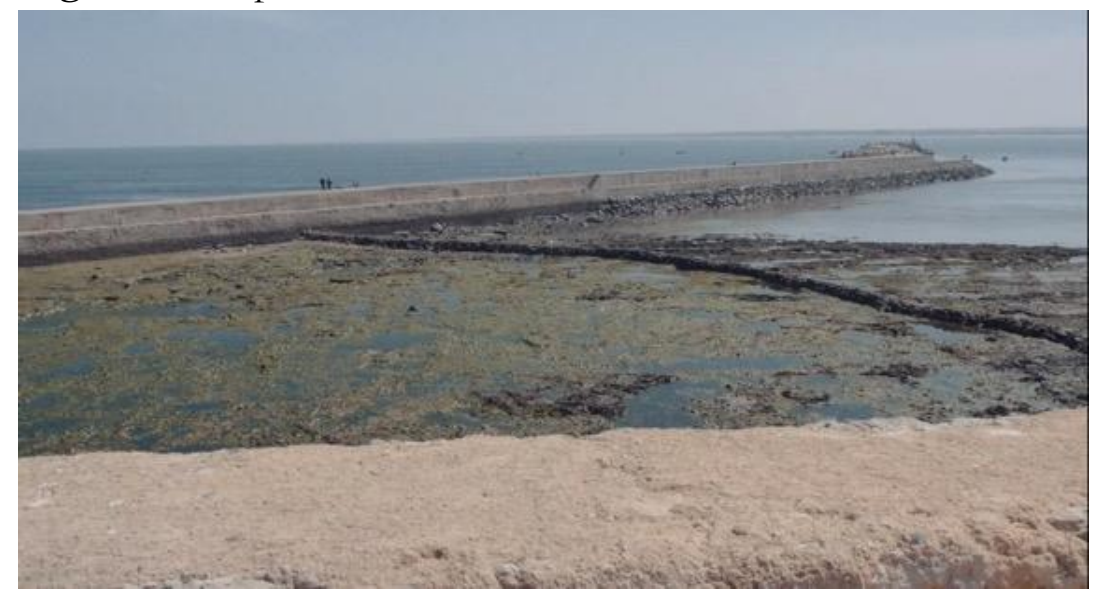

Fonte: MAZAGÃO, 2017.

\section{Referências}

CESAIRE, A. Discurso sobre o colonialismo. Trad. de Noémia de Sousa. Prefácio de Mário de Andrade. Lisboa: Livraria Sá da Costa Editora, 1978.

${ }^{8}$ (MAZAGÃO, 2017, $\left.51 \mathrm{~min}\right)$. 
DELEUZE, G. Nietzsche e a Filosofia. Tradução de Ruth Joffily Dias e Edmundo Fernandes Dias. Rio de Janeiro: Editora Rio, 1976.

DELEUZE, G.; GUATTARI, F. Mistério de Ariadne segundo Nietzsche. In: Crítica e Clínica. Tradução de Peter Pal Pelbart. São Paulo: Editora. 34, 1997.

. O anti-Édipo: capitalismo e esquizofrenia 1. Trad. Luiz B. L. Orlandi. São Paulo: Editora 34, 2010.

Mil Platôs: capitalismo e esquizofrenia. v. 2. Trad. Ana Lúcia de Oliveira e Lúcia Cláudia Leão. São Paulo: Editora 34, 1995/2011a.

. Mil Platôs: capitalismo e esquizofrenia 2. v. 1. (Trad. Ana Lúcia de Oliveira, Aurélio Guerra Neto e Célia Pinto Costa) São Paulo: Ed. 34, 1995/2011b.

Mil Platôs: capitalismo e esquizofrenia 2. v. 3. Trad. Aurélio Guerra Neto, Ana Lúcia de Oliveira, Lúcia Cláudia Leão e Suely Rolnik. São Paulo: Editora 34, 1996/2012.

. Mil Platôs: capitalismo e esquizofrenia 2. v. 5. Tradução Peter Pál Pelbart e Janice Caiafa. São Paulo: Editora 34, 1997/2012a.

. Mil Platôs: capitalismo e esquizofrenia 2. v. 4. Trad. Suely Rolnik. São Paulo: Editora 34, 1997/2012b.

. Maio de 68 não ocorreu. In: DELEUZE, G. Dois Regimes de loucos: textos e entrevistas. São Paulo: Editora 34, 2016. p. 245-248.

FANON, F. Os condenados da terra. Trad. Enilce Albergaria Rocha, Lucy Magalhães. Juiz de Fora: Ed. UFJF, 1961/2005.

MAZAGÃo - Porta do Mar. Direção de Gavin Andrews e Cassandra Oliveira. Produção Espaço Cinema e Vídeo. Com Joseane Calazans, Jozue Videira e Rozicema Viana Barreto. EBC: TV Brasil, 2017. (52 min.) Disponível em:

<https://tvbrasil.ebc.com.br/media-nacional/2017/09/mazagao-porta-do-mar>. Acesso em: 14 set. 2017.

ROLNIK, S. Pensamento, corpo e devir - Uma perspectiva ético/estético/política no trabalho acadêmico. Cadernos de Subjetividade, São Paulo, v. 1, n. 2, p. 241-251, set./fev. 1993. 